\title{
Den strukturelle asymmetri mellem et objekt og et efterfølgende PP-komplement i dansk
}

\section{Sten Vikner}

\begin{abstract}
Looking at verb phrases (VPs) which contain both a direct object and a following preposition phrase (PP), e.g. legge noget på bordet/nettet, 'put something on the table/the web', the picture is perhaps a little confusing. Data from coordination indicate that the object and the $\mathrm{PP}$ form a constituent which excludes the main verb, whereas data from idiomatic expressions point toward the main verb and the PP forming a constituent to the exclusion of the object.

However, these contradictory data can be reconciled by means of the analyses in Larson (1988) and Kratzer (1995), where the object and the PP are not taken to be on the same level in the syntactic structure. This analysis can also account for the fact that such VPs can be modified both by PPs which normally modify only atelic VPs (e.g. $i$ to år 'for two years') and by PPs which normally modify only telic VPs (e.g. på to timer 'in two hours').
\end{abstract}

\section{Nøgleord}

VP, vP, PP-komplement, koordination, idiomatiske udtryk 


\section{Indledning}

I denne $\operatorname{artikel}^{1}$ vil jeg vil se på sætninger med et objekt og en efterfølgende præpositionsfrase, som $\mathrm{fx}^{2}$

\begin{tabular}{|c|c|c|}
\hline Mette vil gerne $\left[_{\mathrm{VP}}\right.$ sende & [DP den her vin] & {$\left[{ }_{\mathrm{PP}}\right.$ til borgmesteren]] } \\
\hline SUBJEKT & OBJEKT & PP-KOMPLEMENT \\
\hline GENS & TEMA & BENEFAKTIV \\
\hline
\end{tabular}

Objektet er her den her vin og det efterfølgende PP-komplement er til borgmesteren. Objektet i denne type eksempler er meget ofte TEMA, hvorimod det efterfølgende PP-komplement alt efter verbet kan få tilskrevet en af en række forskellige tematiske roller, inklusive BENEFAKTIV, som her.

Der er mange forskellige eksempler der til forveksling ligner den type jeg her er interesseret i, og det kan give flertydighed. I et online foredrag den 09.10.2020 sagde Marie Herget Christensen fx følgende om den hjælp hendes projekt havde fået ved dataindsamlingen:

(2) Vi har $\left[_{\mathrm{VP}}\right.$ modtaget ${ }_{\mathrm{DP}}$ en masse trusler $]{ }_{\mathrm{PP}}$ fra politiet og meningsdannere]].

SUBJ

OBJEKT

PP-KOMPLEMENT

hvilket netop er et eksempel af den type jeg vil diskutere. Der var ganske vist en uopdragen tilhører (nemlig undertegnede) som skrev på chatten at det åbenbart var farligt at være lingvist på Københavns Universitet. Den alternative læsning jeg dermed sigtede til, var formentlig følgende hvor det bl.a. er politiet der truer (og det er altså ikke den som den her artikel handler om):

(3) Vi har $\left[_{\mathrm{VP}}\right.$ modtaget $\left[_{\mathrm{DP}}\right.$ en masse trusler fra politiet og meningsdannere]].

SUBJ

OBJEKT

1 Denne artikel er parallel til men ikke identisk med min artikel i MUDS 18, dvs. S. Vikner (2021).

2 DP står for determinativfrase, idet det antages at $\mathrm{fx}$ [den her vin] er bygget op omkring kernen den. PP står for præpositionsfrase, idet fx [til borgmesteren] er bygget op omkring kernen til, ligesom VP står for verbalfrase, idet [sende den her vin til borgmesteren] er bygget op omkring kernen sende. På de efterfølgende sider vil jeg også diskutere andre frasetyper, ligesom jeg vil gå ud fra at mængden af konstituenter altså ikke alene indeholder fraser men også kerner, så som $\mathrm{D}^{\circ}$ (determinativ), $\mathrm{P}^{\circ}$ (præposition) eller $\mathrm{V}^{\circ}$ (verbum). 
Det er faktisk muligt at [ ${ }_{\mathrm{pP}}$ fra politiet og meningsdannere] også er et komplement i (3), men i så tilfælde er det et komplement til substantivet trusler, og ikke til verbet modtage, som i (2).

Man kan kende et komplement til et verbum (uanset om det er en DP eller en PP) på at det er tæt knyttet til verbet. Om et komplement af en bestemt kategori er umuligt, optionelt eller obligatorisk afhænger nemlig af verbet (lase er monotransitivt, give er ditransitivt, og købe kan være enten mono- eller ditransitivt):
a. Ib læste en bog.
d. * Ib læste en bog til Bo.
b. Ib købte en bog.
e. Ib købte en bog til Bo.
c. * Ib gav en bog.
f. Ib gav en bog til Bo.

Adverbialer derimod er i princippet altid (syntaktisk) mulige, jf. at alle de eksempler der er mulige uden adverbialet ${ }_{\mathrm{pp}}$ i ferien $] \mathrm{i}(4)$, dvs. (4)a/b/e/f, også er mulige med dette adverbial i (5):

(5) a. Ib læste en bog i ferien. d.* Iblæste en bog til Bo i ferien.

b. Ib købte en bog i ferien. e. Ibkøbte en bog til Bo i ferien.

c. * Ib gav en bog i ferien. f. Ibgav en bog til Bo iferien.

Komplementer får således deres mening fra verbet, men det gør adverbialer ikke.

Ved hjælp af en flytningstest kan man vise at den her vin er en konstituent i (1), og at til borgmesteren også er det. Testen flytter en konstituent til fundamentfeltet (som vi i generativ syntaks kalder CP-spec).

(6) a. [ ${ }_{\mathrm{PP}}$ Til borgmesteren] vil Mette gerne sende den her vin

b. $\quad[$ DP Den her vin] vil Mette gerne sende

til borgmesteren.

Jeg er godt klar over at man på denne måde ikke alene kan vise at til borgmesteren er en konstituent, (6), men også at borgmesteren er en konstituent, (7), men det finder jeg helt uproblematisk, det viser blot at der kan være andre konstituenter (her: en DP) inden i en PP (jf. kapitel 5 i Nguyen 2020): 
(7) $\quad[\mathrm{DP}$ Borgmesteren] vil Mette gerne sende den her vin $[\mathrm{PP}$ til $]$.

Man kan ikke gøre noget tilsvarende med verbet alene, altså flytte sende til fundamentfeltet. Det viser dog ikke at hovedverbet ikke er en konstituent, men formentlig kun at hovedverbet ikke er en konstituent af den rigtige type: I (7) er sende ikke en konstituent af typen frase (altså ikke en VP = verbalfrase) men kun en konstituent af typen kerne (nærmere bestemt $\mathrm{V}^{\circ}$ = verbum).

* Sende ville Mette gerne den her vin til borgmesteren.

Til gengæld kan man vise at sende den her vin til borgmesteren er en konstituent som er en frase (nemlig VP):

(9) $\quad[\mathrm{vP}$ Sende den her vin til borgmesteren] ville Mette gerne , men hun turde ikke.

Igen ser vi at konstituenter kan indeholde andre konstituenter, selv inden for samme sætning.

Hvordan er så den interne struktur i sådan en VP med et objekt efterfulgt af et PP-komplement? Der findes to oplagte men efter min mening galt afmarcherede analyser, en med tre døtre af VP, (10), og en hvor verbet og objektet udgør en konstituent uden PP'en, $(11)^{3}$ :

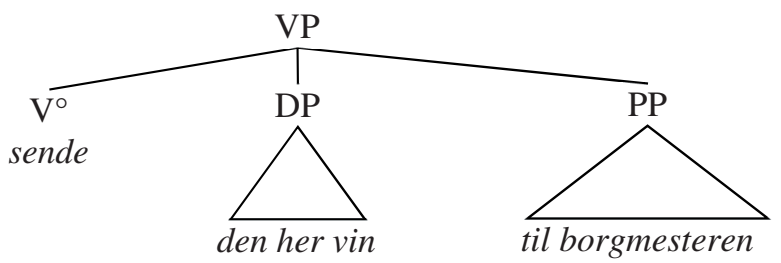

3 Der er sådan set ikke noget galt med (11), bortset fra at den forudsætter at PP'en er et adverbial og ikke et komplement til verbet. Dermed kan (11) ikke være en analyse af et eksempel som (1), hvor PP'en til borgmesteren helt klart er et komplement, men (11) er derimod velegnet som analyse af $\mathrm{fx}$ (5)a, hvor PP'en i ferien netop er et adverbial. 


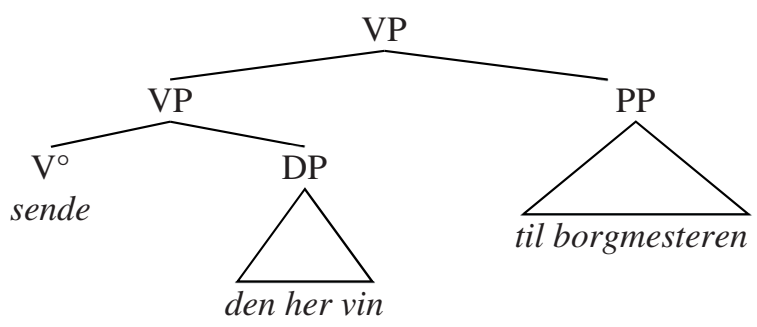

Jeg vil forsøge at vise at der er (mindst) to ting i vejen med både (10) og (1 1):

- Data med koordinationer viser at vi har brug for en konstituent der består af objektet og det efterfølgende PP-komplement men som ikke inkluderer verbet - afsnit 2 .

- Data med idiomatiske udtryk viser at vi har brug for en konstituent der består af verbet og PP-komplementet (!) men som ikke inkluderer objektet - afsnit 3 .

Jeg vil derfor foreslå en revideret version af analysen i (10) og (11) i afsnit 4 , og derefter vil jeg underbygge den med data vedrørende temporal modifikation af VP i afsnit 5.

\section{Koordination}

Jeg går ud fra at en koordinator koordinerer to konstituenter, som i den nedenstående stærkt forenklede analyse (hvor koordination ses som en undtagelse både fra kravet om binær forgrening og fra kravet om at enhver frase er en projektion af en kerne): ${ }^{4}$

4 AdjP står for adjektivfrase, altså en frase bygget op omkring et adjektiv. IP står for inflektionsfrase, som tilsvarende er en frase bygget op omkring inflektionspositionen, og som i en dansk hovedsætning indeholder alt hvad der står til højre for det finitte verbum, og i en dansk indlejret sætning indeholder alt hvad der står til højre for fx at, om, som, når, selvom, se fx (34) og (35) nedenfor eller S. Vikner \& Jørgensen (2017: 139, 147, 160-162). 
(12)

a.

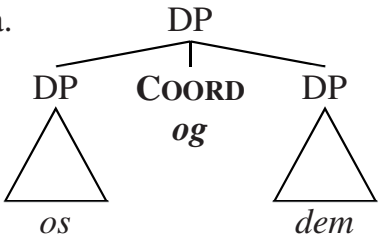

c.

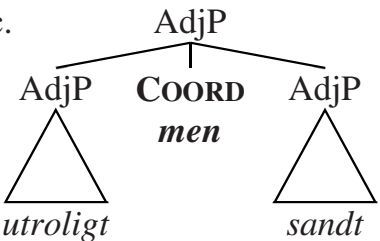

b.

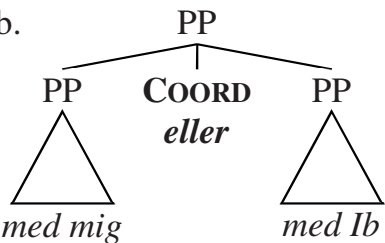

d.

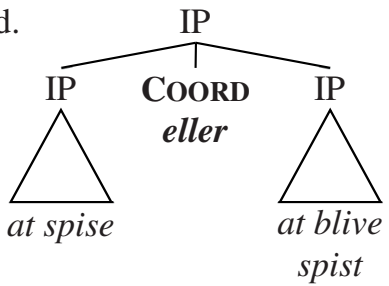

Det koordinationsrelaterede problem for analyserne i (10) og (11) er at man kan sige (13) (men dog ikke (14)):

(13) Mette ville egentlig have sendt

[en flaske whisky til den franske ambassadør] og [en flaske cognac til den irske generalkonsul].

(14) *Mette ville egentlig have sendt en [flaske whisky til den franske ambassadør] og [flaske cognac til den irske generalkonsul].

Hvis de firkantede parenteser markerer konstituenter i (13) men ikke i (14), ville man forvente netop dette resultat. Problemet er så at i analyserne i (10) og (11) findes der ikke nogen konstituent der består udelukkende af objektet og PP'en, selvom det er det der understøttes af (13).

\section{Idiomatiske udtryk}

Som i S. Vikner (2018: 196) vil jeg her antage at de dele af en sætning der udgør et idiomatisk udtryk, også udgør en konstituent (som antaget helt fra Perlmutter 1970: 109 og op til fx Hornstein, Nunes \& Grohmann 2005: 81; og Radford 2009: 242; Larson 2010: 319; Carnie 2011: 264; Poole 2011 : 273; Koeneman \& Zeijlstra 2017: 160).

Det idiomatiske udtryk kan udgøres af hele sætningen, (15), hvilket kan ses ved to ting: 
- Hvis man ændrer en af sætningens interne konstituenter, så taber man den idiomatiske læsning. ${ }^{5}$

- I den idiomatiske læsning har ingen af de pågældende konstituenter deres normale reference.
a. ... før fanden
fik sko på. KAN FORSTÅS IDIOMATISK
b. \# ... før troldmanden fik sko på.
ELLER BOGSTAVELIGT
c. \# ... før fanden
tog sko på.
KUN BOGSTAVELIGT
d. ${ }^{\#}$... før fanden
fik støvler på. KUn BOGSTAVELIGT

Det er ligeledes muligt at kun VP udgør et idiomatisk udtryk, (16), hvilket kan ses ved de samme to ting:

- Hvis man ændrer en af VP'ens interne konstituenter, så taber man den idiomatiske læsning.

- I den idiomatiske læsning har ingen af de pågældende konstituenter deres normale reference.

Derimod kan man godt ændre subjektet, ligesom subjektet beholder sin normale reference, det er jo netop ikke en del af VP:
a. Otto har lugtet
$\underline{\text { lunten. }}$
IDIOMAT./BOGST.
b. Jens har lugtet
lunten.
IDIOMAT./BOGST.
c. \# Otto har bemærket lunten.
KUN BOGST.
d. ${ }^{*}$ Otto har lugtet
tændsnoren.
KUN BOGST.

Også i sætninger med et objekt og et efterfølgende PP-komplement, (17) og (18), kan hele VP udgøre et idiomatisk udtryk:

5 Ved fagfællebedømmelsen både af denne artikel og af S. Vikner (2021) blev det bemærket at i hvert fald nogle af de eksempler som jeg begrænser til kun at have en bogstavelig fortolkning, fx (17)e, også kan fortolkes på en måde som en fagfællebedømmer kalder "leg med idiomet" (det kunne være noget i stil med Mette skal ikke bare altid male fanden på voggen men også på ruden og på køkkenbordet). Det er jeg enig i, men jeg vil dog fastholde at sådanne eksempler har en helt anden og meget mere kontekstafhængig status end den der gælder for de eksempler ovenfor hvor jeg har angivet en mulig idiomatisk fortolkning. 
(17) a. Mette skal altid male fanden på væggen. IDIOMAT./BOGST.

b. Sofie skal altid male fanden på væggen. IDIOMAT./BOGST.

c. \# Mette skal altid tegne fanden på væggen. KUN BOGST.

d. \# Mette skal altid male den onde på væggen. KUn BOGST.

e. \# Mette skal altid male fanden på ruden. KUn BOGST.

(18) a. Mette gjorde en myg til en elefant.

IDIOMAT./BOGST.

b. Jakob gjorde en myg til en elefant.

c. ${ }^{*}$ Mette tryllede en myg til en elefant.

IDIOMAT./BOGST.

d. \# Mette gjorde en flue til en elefant.

KUN BOGST.

e. ${ }^{\#}$ Mette gjorde en myg til en flodhest.

KUN BOGST.

KUN BOGST.

Det forhold der er bemærkelsesværdigt i forbindelse med idiomatiske udtryk i sætninger med et objekt og et efterfølgende PP-komplement, er at verbet kan udgøre et idiomatisk udtryk sammen med PP-komplementet uden at objektet er inkluderet i det (selvom objektet står mellem verbet og PP'en):
a. Mette kastede Frank for løverne.
b. Lars kastede Frank for løverne.
c. \# Mette puffede Frank for løverne.
d. Mette kastede Lars for løverne.
e. \# Mette kastede Frank for tigrene.

IDIOMAT./BOGST.

IDIOMAT./BOGST.

KUN BOGST.

IDIOMAT./BOGST.

KUN BOGST.

(20) a. Otto lagde lingvistikken på hylden.

IDIOMAT./BOGST.

b. Jens lagde lingvistikken på hylden.

IDIOMAT./BOGST.

c. \# Otto anbragte lingvistikken på hylden.

KUN BOGST.

d. Otto lagde fysikken på hylden.

IDIOMAT./BOGST.

e. \# Otto lagde lingvistikken på reolen.

KUN BOGST.

Dette afsnit har altså vist at der er brug for en analyse af VP'er med et objekt og et efterfølgende PP-komplement hvor verbet udgør en konstituent sammen med PP-komplementet.

\section{4. vP/VP-analysen}

Den analyse jeg her vil foreslå, bygger på den idé at et verbum med et objekt og et efterfølgende PP-komplement, fx sende eller lagge, udgør et 
komplekst kausativt prædikat med betydningen " $\mathrm{X}$ forårsager at $\mathrm{Y}$ befinder sig hos Z". ${ }^{6}$

I (21)a er den her vin objektet, og til borgmesteren er PP-komplementet. Handlingen beskrevet i (21)a forårsager resultatet i (21)b, hvor den her vin nu er subjektet:
a. Mette sender den her vin til borgmesteren.
HANDLING /
ÅRSAG
b. Den her vin er
hos borgmesteren.
RESULTAT

Parallellerne mellem (21)a,b er det som analysen i (22) nedenfor forsøger at udtrykke med to verbalfraser i stedet for én, hvor den nedre verbalfrase kaldes VP og den øvre verbalfrase kaldes vP. Denne analyse går tilbage til Larson (1988), Chomsky (1995: 280-290, 302-307), Kratzer (1995) og S. Vikner (1989); og mere specifikt vedrørende V-DP-PP til Schütze og Gibson (1999), Bruening (2010) og Harley og Jung (2015).

VP og vP kaldes ofte for VP-shells, 'VP-skaller' eller 'VP-lag', og idéen er at de er forskellige versioner af den samme $\mathrm{VP}^{7}$, fx har de det samme ditransitive verbum, her sende, som kerne. I den nedre VP er PP-komplementet komplement til verbet, og objektet er specifikator (VP-spec). Den nedre VP udtrykker den resulterende tilstand, (21)b, og den øvre $\mathrm{vP}$ (som jo indeholder den nedre VP) udtrykker hele handlingen, (21)a. Det ditransitive verbum flytter altid fra den nedre kerneposition, $\mathbf{V}^{\circ}$, til den øvre, $\mathbf{v}^{\circ}$, hvor det står til venstre for begge komplementer. Dette sker bl.a. fordi verbet skal flytte til en position hvor det kan tilskrive sin tredje og sidste tematiske rolle til subjektet. Således kan strukturen og denne flytning ses som en konsekvens af den binære forgrening og af det at en kerne kun kan tilskrive tematiske roller til sin komplement-position og til sin specifikator-position.

6 Som en fagfællebedømmer påpeger, er dette en antagelse der også findes i andre teoretiske tilgange, jf. fx Goldberg (1992).

7 Det er desuden denne vP/VP-analyse som Nyvad et al. (2017) og S. Vikner et al. (2017) appellerer til når de foreslår en cP/CP-analyse, og som Nguyen (2020: 234) appellerer til når han foreslår en $\mathrm{pP} / \mathrm{PP}$-analyse. 
(22)

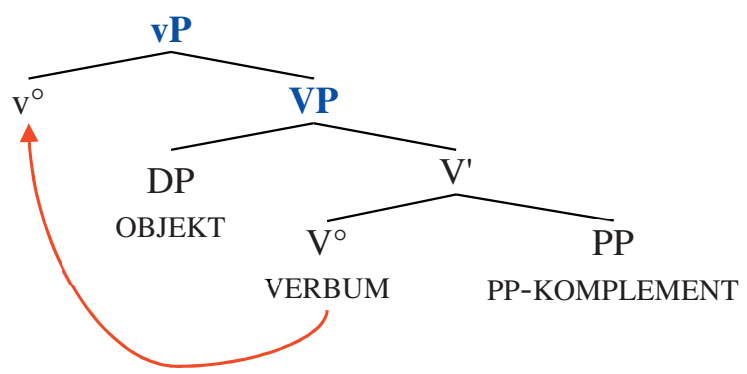

(23)

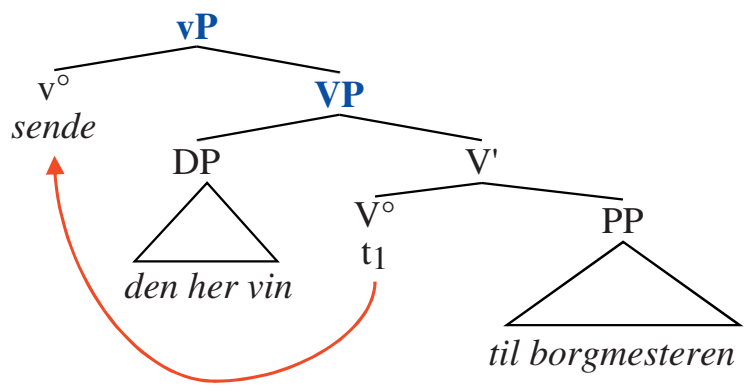

Hermed har vi også en analyse der kan håndtere de problematiske data i de to foregående afsnit:

- Den koordinerede konstituent i (13) = (24) svarer således til den nedre VP i (22)/(23):

(24) Mette ville egentlig have sendt

[en flaske whisky til den franske ambassadør] og [en flaske cognac til den irske generalkonsul].

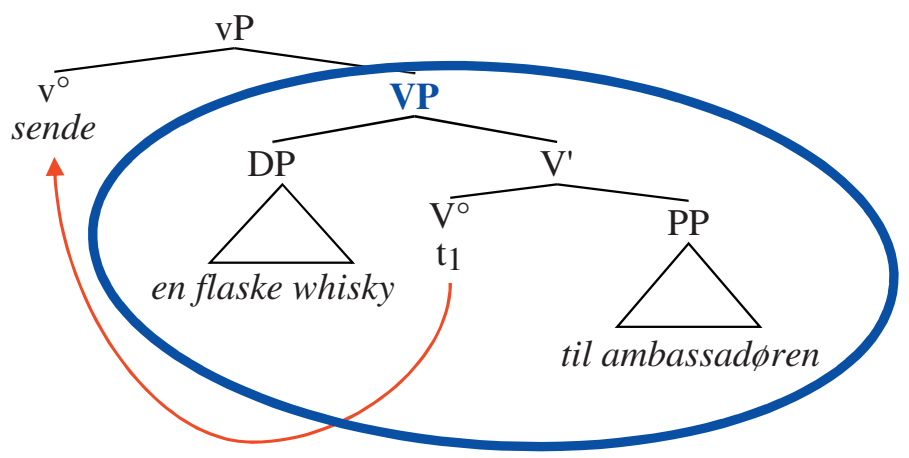


- Den idiomatiske del af (20)a = (26), altså de dele af (20)a = (26) der ikke har deres normale reference (der er ikke noget der bliver lagt, og der er heller ingen hylde involveret), danner faktisk også en konstituent. Før verbet flytter fra $\mathrm{V}^{\circ}$ til $\mathrm{v}^{\circ}$, danner det nemlig en konstituent $\left(\mathrm{V}^{\prime}\right)$ sammen med PP-komplementet. Dette kan også ses efter verbalflytningen, som vist i (26), ved at det allernederste spor af verbet danner en konstituent (stadig V') sammen med PP-komplementet. Det er derfor at verbet og PP-komplementet tilsammen kan udgøre den idiomatiske del af sætningen, også selvom verbet og PP'en ikke står ved siden af hinanden.

(26)

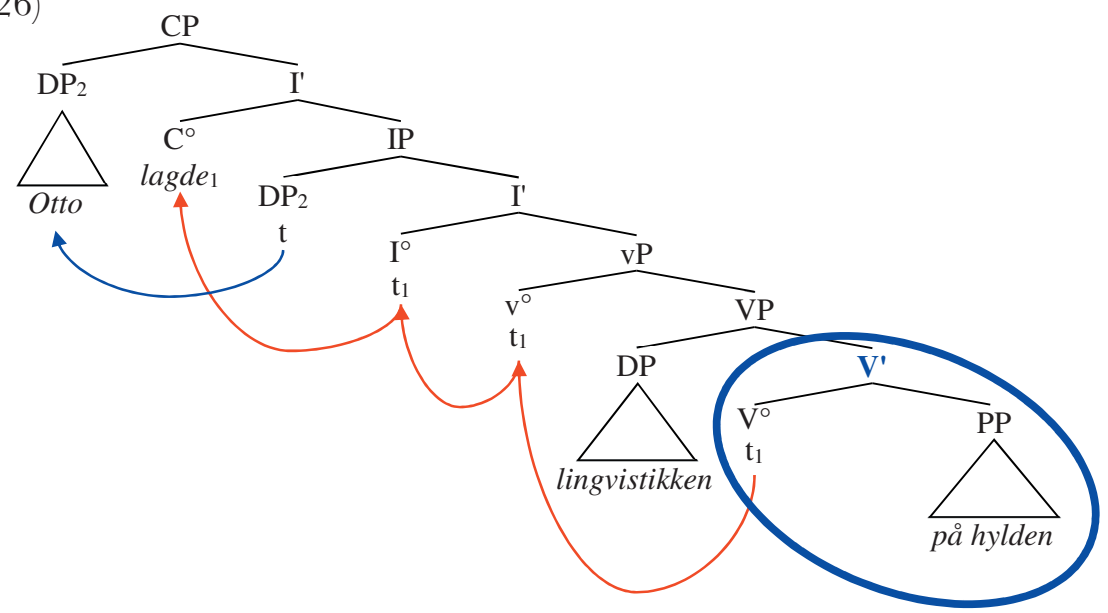

Denne vP/VP-analyse, hvor VP udtrykker den resulterende tilstand, og hvor vP udtrykker hele det komplekse kausative prædikat " $\mathrm{X}$ forårsager at $\mathrm{Y}$ er hos Z, eller at Z har Y", finder anvendelse ikke alene ved den type ditransitive verber som diskuteres i denne artikel (V-DP-PP, Mette sender den her vin til borgmesteren) men også ved en anden type ditransitive verber, nemlig dem der har et indirekte og et direkte objekt (V-DP-DP, Mette forerer partilederen den her vin), som diskuteret i S. Vikner (2021).

Den resulterende tilstand, (21)b, ved ditransitive V-DP-PP-verber, som jeg formulerede "Y er hos Z", svarer dermed til den resulterende tilstand ved ditransitive V-DP-DP-verber, hvor den dog i stedet skal formuleres " $\mathrm{Z}$ har Y". Analysen bringer således klart frem at det der adskiller de to typer ditransitive verber (V-DP-PP og V-DP-DP), er at deres resulterende tilstande er henholdsvis en vare hos-relation og en have-relation (se også fx Benveniste 1966: 198-199; Freeze 1992: 576-585; og Kayne 1993: 4, 2000: 108). 


\section{Temporal modifikation af $\mathrm{vP} / \mathrm{VP}$}

Det sidste datasæt der skal nævnes i forbindelse med analysen af sætninger med en VP med et objekt og et PP-komplement, som i (22)/(23), har med temporal modifikation at gøre.

Som i Vikner og Vikner (1997: 270) (og i de behandlinger vi refererer til der) antager jeg (mindst) følgende aspektuelle verbalklasser (Aktionsarten):

\section{ASPEKTUELLE VERBALKLASSER (AKTIONSARTEN):}
a. Ib hader ost.
b. Ib dansede
TILSTAND
til festen.
PROCES
$\bullet \bullet \bullet-\bullet \bullet \bullet-\bullet-\bullet \bullet \bullet \bullet-\bullet \bullet \bullet-\bullet-\bullet \bullet \bullet$ (= ACTIVITY)
c. Ib byggede KOMPLEKS BEGIVENHED
huset. (= ACCOMPLISHMENT)
d. Ib genkendte $\sin$ PUNKTUEL BEGIVENHED gamle ven. (= ACHIEVEMENT)

Som beskrevet fx i C. Vikner (1994: 148-149) (og mange andre steder, inkl. Vendler 1967: 101; Fillmore 1975: 36; Dowty 1979: 56, 60; Dahl 1981: 79, 84; Krifka 1989: 166-170, 1992: 32; Smith 1991: 68-71) er der forskel på hvilke typer temporal modifikation der er mulige, alt efter om den pågældende aspektuelle verbalklasse er telisk (har et naturligt slutpunkt) eller atelisk:

TILSTANDE

(28) a. ... fordi hun savnede lakrids i tre år.

(ATEliske, PP Med $i$ )

b. * ... fordi hun savnede lakrids på tre år.

PROGESSER

(ATELISKe, PP MED $i$ )

(29) a. ... fordi han ledte efter bogen i en halv time.

b. *... fordi han ledte efter bogen på en halv time.

(30) a. ... fordi de arbejdede som tømrere i tre år.

b. * ... fordi de arbejdede som tømrere på tre år.

KOMPLEKSE BEGIVENHEDER

(TELISKe, PP MED $p a ̊)$

(31) a. * ... fordi han fandt bogen i en halv time.

b. ... fordi han fandt bogen på en halv time. 
(32) a. * ... fordi de byggede huset i tre måneder.

b. $\quad$... fordi de byggede huset på tre måneder.

Det interessante ved sætninger med et objekt og et efterfølgende PPkomplement som i (22)/(23) er at i hvert fald nogle af dem tillader begge typer temporal modifikation:
a. ... fordi hun placerede pengene på sin sydafrikanske konto i to måneder.
b. ... fordi hun placerede pengene på sin sydafrikanske konto på to minutter.

Det passer godt sammen med analysen i (22)/(23): Her er VP en resulterende tilstand (atelisk, temporal modifikation med en PP med $i$ ) samtidig med at hele vP er en kompleks begivenhed (telisk, temporal modifikation med en PP med $p a ̊)$ :

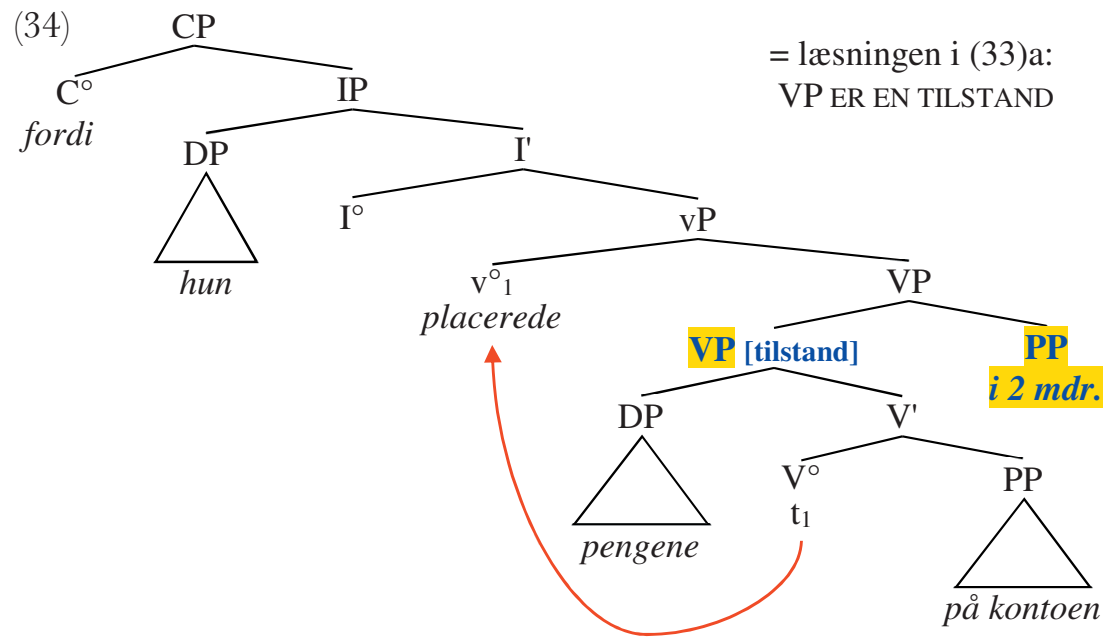


(35)

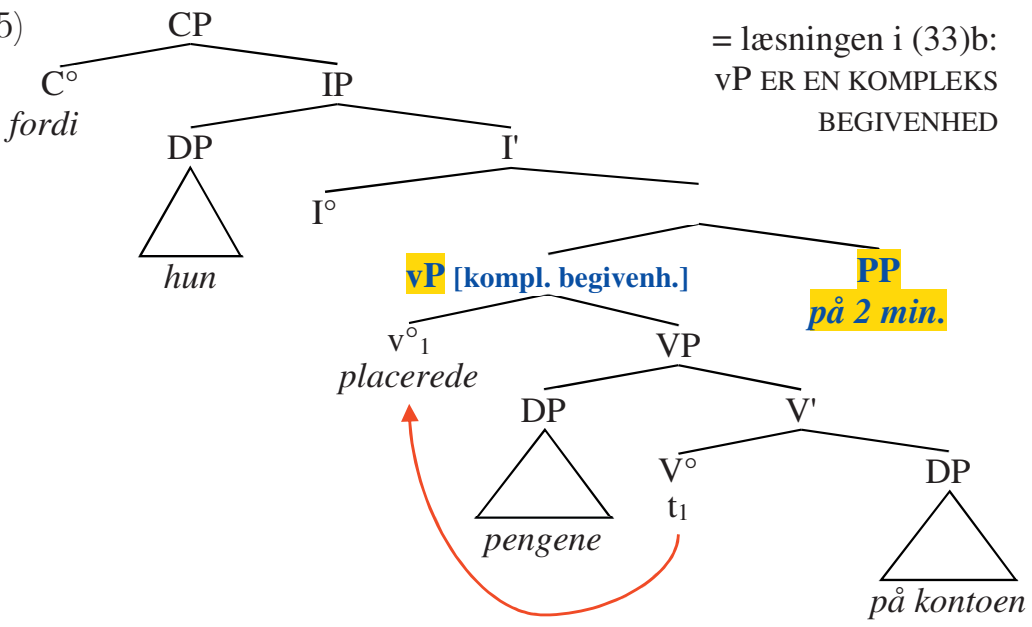

Der er dog endnu en forudsigelse som ikke er helt uproblematisk, bl.a. fordi den er svær at efterprøve. Analyserne i (34) og (35) forudsiger nemlig at $i$-PP'en skal komme før på-PP'en, dvs. at (36)a er bedre end (36)b:
a. $\quad$... fordi hun placerede pengene på sin sydafrikanske konto i to måneder på to minutter. b. ?? ... fordi hun placerede pengene på sin sydafrikanske konto på to minutter i to måneder.

Dette passer med min intuition og med intuitionerne hos de lingvister ${ }^{8}$ jeg har konsulteret, men det er svært at underbygge, idet der ikke findes nogen eksempler i fx KorpusDK med begge typer af temporale PP'er i den samme sætning.

I dette afsnit har jeg prøvet at vise hvorledes en analyse med både vP og VP kan redegøre for at (33)a,b kan tolkes både atelisk og telisk, hvilket fremgår af at modificering er mulig både med en på-PP og med en $i$-PP.

Denne analyse medfører også en forudsigelse vedrørende mulige og umulige rækkefølger af en på-PP og en $i$-PP i (36)a,b, men her er data måske ikke helt så klare.

8 Inklusive publikum ved Grammatiknetværkets onlinekonference i oktober 2020. 


\section{Konklusion}

Denne $\operatorname{artikel}^{9}$ har argumenteret for en lidt kompliceret analyse af VP'er med et objekt efterfulgt af et PP-komplement.

I afsnit 2 så vi at data med koordinationer viser at der er brug for en konstituent der består af objektet og det efterfølgende PP-komplement men som ikke inkluderer verbet.

I afsnit 3 viste data med idiomatiske udtryk at der var brug for en konstituent der består af verbet og PP-komplementet men som ikke inkluderer objektet.

Afsnit 4 foreslog derfor en lidt kompliceret analyse af VP'er med et objekt efterfulgt af et PP-komplement for at kunne redegøre for data fra de to foregående afsnit:

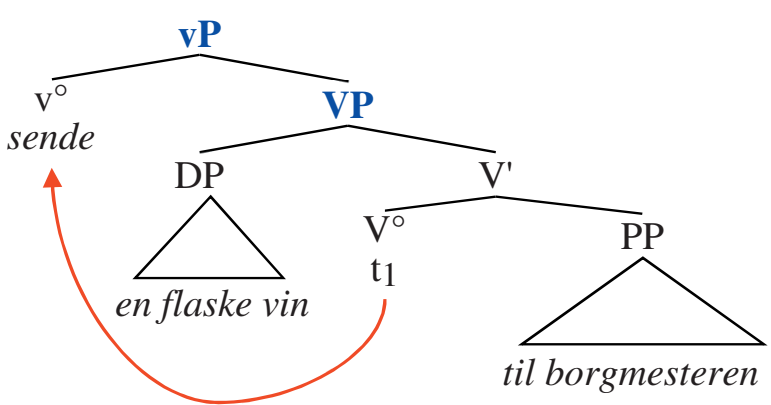

Endelig viste afsnit 5 at denne analyse kunne bruges til redegøre for hvorfor denne type sætninger (som i (33)a,b) ser ud til at kunne tolkes både atelisk og telisk, idet modificering er mulig både med en på-PP og med en $i$-PP.

9 Tak til Ken Ramshøj Christensen, Katrine Rosendahl Ehlers, Eva Skafte Jensen, Henrik Jørgensen, Johannes Kizach, Henrik Høeg Müller, Michael Nguyen, Anne Mette Nyvad, Helle Kaalund Tornbo og Carl Vikner, til en anonym fagfællebedømmer, til publikum ved Grammatiknetværkets online konference i oktober 2020 og ikke mindst til de studerende i mine kurser om komparativ syntaks. Forskningen bag denne artikel var en del af to forskningsprojekter ved Aarhus Universitet, finansieret af Forskningsrådet for Kultur og Kommunikation: Objektspositioner - komparativ syntaks $i$ et tverteoretisk perspektiv og Ligheder og forskelle mellem satninger og nominalgrupper - sammenlignende syntaks på tocars af teoretiske tilgange. 


\section{Om forfatteren}

Sten Vikner, professor i engelsk lingvistik, dr.phil.habil., Institut for Kommunikation og Kultur, Aarhus Universitet

\section{Litteratur}

Benveniste, É. (1966): Problèmes de linguistique générale. Paris: Gallimard.

Bruening, B. (2010): Ditransitive Asymmetries and a Theory of Idiom Formation. Linguistic Inquiry, 41(4), 519-562. doi:10.1162/LING_a_00012.

Carnie, A. (2011): Modern Syntax: A Coursebook. Cambridge: Cambridge University Press. doi:10.1017/CBO9780511780738.

Chomsky, N. (1995): The Minimalist Program. Cambridge, MA: MIT Press. Dahl, Ö. (1981): On the Definition of the Telic-Atelic (Bounded-Unbounded) Distinction. P.J. Tedeschi \& A. Zaenen (red.), Tense and Aspect. New York: Academic Press (Syntax and Semantics), 79-90.

Dowty, D. (1979): Word meaning and Montague grammar: the semantics of verbs and times in generative semantics and in Montague's PTQ. Dordrecht: Reidel.

Fillmore, G. (1975): Santa Cruz Lectures on Deixis, 1971. Bloomington: Indiana University Linguistics Club.

Freeze, R. (1992): Existentials and Other Locatives. Language, 68(3), 553595. doi:10.2307/415794.

Goldberg, A. E. (1992): The inherent semantics of argument structure: The case of the English ditransitive construction. Cognitive Linguistics, 3(1), 37-74. doi:10.1515/cogl.1992.3.1.37.

Harley, H. \& H.K. Jung (2015): In Support of the P-HAVE Analysis of the Double Object Construction. Linguistic Inquiry, 46(4), 703-730. doi:10.1162/LING_a_00198.

Hornstein, N., J. Nunes \& K.K. Grohmann (2005): Understanding minimalism. Cambridge: Cambridge University Press. doi:10.1017/ CBO9780511840678.

Kayne, R. S. (1993): Toward a Modular Theory of Auxiliary Selection. Studia Linguistica, 47(1), 3-31. doi:10.1111/j.1467-9582.1993.tb00837.x.

Kayne, R. S. (2000): Parameters and Universals. Oxford: Oxford University Press.

Koeneman, O. \& H. Zeijlstra (2017): Introducing Syntax. Cambridge: Cambridge University Press. doi:10.1017/9781316156391.

Kratzer, A. (1995): Severing the External Argument from its Verb. I: Rooryck, J. \& L. Zaring (red.), Phrase Structure and the Lexicon. Dordrecht: 
Kluwer, 109-137. https://www.springer.com/gp/book/9780792337454 (lokaliseret 19.09.2019).

Krifka, M. (1989): Nominalreferenz und Zeitkonstitution: zur Semantik von Massentermen, Pluraltermen und Aspektklassen. München: W. Fink.

Krifka, M. (1992): Thematic Relations as Links between Nominal Reference and Temporal Constitution. I: Sag, I.A. \& Szabolcsi, A. (red.), Lexical Matters. Stanford CA: CSLI Publications, 29-53.

Larson, R.K. (1988): On the Double Object Construction. Linguistic Inquiry, 19(3), 335-391. http://www.jstor.org/stable/25164901 (lokaliseret 01.05.2021).

Larson, R.K. (2010): Grammar as science. Cambridge, MA: MIT Press.

Nguyen, M. (2020): A grammar of the adpositional phrase in Danish: On left located adpositional complements. $\mathrm{PhD}$ dissertation. Aarhus University.

Nyvad, A.M., K.R. Christensen \& S. Vikner (2017): CP-Recursion in Danish: A cP/CP-Analysis. The Linguistic Review, 34(3), 449-477. doi:10.1515/ tlr-2017-0008.

Perlmutter, D. (1970). The two verbs "begin". I: Jacobs, R.A. \& P.S. Rosenbaum (red.), Readings in English transformational grammar. Waltham, MA.: Ginn \& Co, 107-119.

Poole, G. (201 1): Syntactic theory. 2nd edn. Basingstoke: Palgrave Macmillan. Radford, A. (2009): Analysing English Sentences: A Minimalist Approach. Cambridge: Cambridge University Press. doi:10.1017/CBO9780511801617. Schütze, C.T. \& E. Gibson (1999): Argumenthood and English Prepositional Phrase Attachment. Fournal of Memory and Language, 40(3), 409-431. doi:10.1006/jmla.1998.2619.

Smith, C.S. (1991): The parameter of aspect. Dordrecht: Reidel.

Vendler, Z. (1967): Linguistics in philosophy. Ithaca, NY: Cornell University Press.

Vikner, C. (1994): Change in homogeneity in verbal and nominal reference. I: Bache, C., H. Basbøll \& C.E. Lindberg (red.), Tense, Aspect and Action: Empirical and Theoretical Contributions to Language Typology. Berlin: Mouton De Gruyter, 139-164. doi:10.1515/9783110883077.139.

Vikner, C. \& S. Vikner (1997): The Aspectual Complexity of the Simple Past in English - A Comparison with French and Danish. I: Bache, C. $\&$ A. Klinge (red.), Sounds, Structures and Senses - Essays Presented to Niels Davidsen-Nielsen on the Occasion of his Sixtieth Birthday. Odense: Syddansk Universitetsforlag, 267-284. https://tildeweb.au.dk/au132769/papers/ vikn97d.pdf (lokaliseret 01.05.2021).

Vikner, S. (1989): Object Shift and Double Objects in Danish. Working Papers 
in Scandinavian Syntax, 44, 141-155. https://tildeweb.au.dk/au132769/ papers/vikn89a.pdf (lokaliseret 01.05.2021).

Vikner, S. (2018). Sætningsstruktur og idiomatiske vendinger. I: Lyshøj, K., V. Sørensen \& I.S. Hansen (red.), Fraseologi - genveje og omveje: Festskrift til Torben Arboe $i$ anledning af hans 70-ärsdag den 8. september 2018. Aarhus: Peter Skautrup Centret for Jysk Dialektforskning, 193-198. https:// tildeweb.au.dk/au132769/papers/vikn18b.pdf (lokaliseret 01.05.2021).

Vikner, S. (2021): Den strukturelle asymmetri mellem det indirekte og det direkte objekt i dansk. Under udgivelse i MUDS - Møderne om Udforskningen af Dansk Sprog, 18. https://tildeweb.au.dk/au132769/papers/vikn21a. pdf (lokaliseret 01.05.2021).

Vikner, S., K.R. Christensen \& A.M. Nyvad (2017): V2 and cP/CP. I: Bailey, L. \& M. Sheehan (red.), Order and structure in syntax I. Berlin: Language Science Press, 313-324. doi:10.5281/zenodo.1117724.

Vikner, S. \& H. Jørgensen (2017): En formel vs. en funktionel tilgang til dansk sætningsstruktur. Nydanske Sprogstudier - NyS, 52-53, 135-168. doi:10.7146/nys.v1i52-53.24954. 